Edukacja Dorostych 2021, nr 2

ISSN 1230-929 X

http://dx.doi.org/10.12775/ED.2021.020

\title{
Hanna Achremowicz
}

ORCID 0000-0003-3398-0124

Roksana Pilawska-Gronostaj

ORCID 0000-0002-5451-8249

\section{SPRAWOZDANIE Z XXXIII KONFERENCJI NAUKOWEJ FORUM PEDAGOGÓW}

W dniach 26-27 października 2021 roku odbyło się XXXIII Forum Pedagogów, cykliczna konferencja naukowa, która tym razem miała szczególny charakter. Oprócz części stricte naukowej konferencja wrocławska stała się okazją do uhonorowania profesora Jerzego Semkowa, który był jednym z pomysłodawców idei spotkań w ramach Forum Pedagogów. Tematyka tegorocznej konferencji ogniskowała się na problematyce andragogicznej, którą określał tytuł (Z)rozumieć teraźniejszość, myśleć o przyszłości - między wizja a praktyka w edukacji dorosłych. Została ona zorganizowana przez Zakład Edukacji Dorosłych i Studiów Kulturowych oraz Pracownię Metodologii Badań nad Edukacją Instytutu Pedagogiki Uniwersytetu Wrocławskiego. Konferencja została objęta patronatem honorowym Rektora Uniwersytetu Wrocławskiego prof. dr. hab. Przemysława Wiszewskiego. Patronat naukowy nad wydarzeniem objęło Akademickie Towarzystwo Andragogiczne. Organizację konferencji wspierali: doktorantki Szkoły Doktorskiej (Roksana Pilawska-Gronostaj i Hanna Achremowicz), studenci kierunku pedagogiki, specjalność: Edukacja Dorosłych i Marketing Społeczny oraz członkowie Interdyscyplinarnego Koła Naukowego Variograf.

Jak trafnie zauważyli organizatorzy konferencji, w obliczu dynamicznych zmian otaczającego nas świata doświadczanie codzienności i jej (z)rozumienie staje się realnym wyzwaniem dla współczesnego człowieka. Każdego dnia jesteśmy obserwatorami, świadkami i uczestnikami przemian społecznych, kulturowych, politycznych, ekonomicznych, technologicznych czy ekologicznych. Z jednej strony, człowiek coraz częściej staje w obliczu nagłej konieczności redefinicji lub wypracowania takiej wiedzy, zachowań, norm czy postaw, które wiążą się z rzeczywistością naznaczoną podziałami, niesprawiedliwością, ograniczeniami, dystansem społecznym, izolacją, obostrzeniami, zakazami, lękiem, niepewnością 
i utratą. $Z$ drugiej natomiast, można dostrzec ogromne możliwości i edukacyjny potencjał współczesności, dzięki którym człowiek ma możliwość nieustannego rozwoju. Stawia przed sobą pytania: Kim jestem? W jaki sposób się staję? Czego potrzebuję? W jakim kierunku zmierzam? W takiej perspektywie podjęcie naukowej refleksji nad dorosłością, procesem uczenia się i edukacją człowieka dorosłego nabiera szczególnego znaczenia.

W konferencji udział wzięli przedstawiciele kilkunastu krajowych ośrodków akademickich m.in. z: Uniwersytetu im. Adama Mickiewicza w Poznaniu, Uniwersytetu Łódzkiego, Uniwersytetu Pedagogicznego im. KEN w Krakowie, Uniwersytetu im. Mikołaja Kopernika w Toruniu, Uniwersytetu Warszawskiego, Dolnośląskiej Szkoły Wyższej we Wrocławiu, Akademii WSB w Dąbrowie Górniczej, Akademii Pedagogiki Specjalnej im. Marii Grzegorzewskiej w Warszawie.

Uroczystego otwarcia konferencji i okolicznościowego powitania zebranych gości dokonali Dyrektor Instytutu Pedagogiki Uniwersytetu Wrocławskiego, dr hab. Alicja Szerląg, prof. UWr, dziekan Wydziału Nauk Historycznych i Pedagogicznych dr hab. Paweł Klint, prof. UWr, Przewodnicząca Komitetu Naukowo-Organizacyjnego, dr Joanna Golonka-Legut oraz dr hab. Witold Jakubowski, prof. UWr., kierownik Zakładu Edukacji Dorosłych i Studiów Kulturowych. Był to jednocześnie moment powitania szanownego jubilata - emerytowanego profesora Uniwersytetu Wrocławskiego Jerzego Semkowa. Jego dawni studenci, obecnie doktorzy i profesorowie, a także liczne grono Profesorów reprezentujących różne środowiska pedagogów i andragogów, złożyli mu serdeczne życzenia. Prof. dr hab. Ewa Solarczyk-Ambrozik odczytała również specjalny adres na tę szczególną okoliczność, przygotowany we współpracy z Panią Dziekan Wydziału Studiów Edukacyjnych Uniwersytetu im. Adama Mickiewicza prof. dr hab. Agnieszką Cybal-Michalską, przewodniczącą KNP PAN. W imieniu Władz Zarządu Akademickiego Towarzystwa Andragogicznego list gratulacyjny skierowany do jubilata odczytała Pani Prezes Zarządu ATA dr hab. Hanna Solarczyk-Szwec, prof. UMK. Wspólnie wspominaliśmy pracę, życzliwość oraz wkład Profesora Jerzego Semkowa w rozwój naukowy wielu pokoleń.

Pierwszego dnia konferencji w sesji plenarnej dotyczącej procesu uczenia się dorosłych w czasach zmiany udział wzięli kolejno: prof. dr hab. Teresa Hejnicka-Bezwińska, która przedstawiła istotę praktyki edukacyjnej w obliczu zmian kulturowych ostatniego 80-lecia, prof. dr hab. Ewa Solarczyk-Ambrozik, opowiadająca o zjawisku edukacyjnej ekspansji i trendach rozwoju szkolnictwa wyższego w perspektywie globalnej, dr hab. Ewa Kurantowicz, prof. DSW, która odnosiła się do relacji uniwersytetu i społeczności w edukacyjnej perspektywie dziedzictwa kulturowego oraz prof. dr hab. Elżbieta Dubas, przedstawiająca znaczenie biografii rodzinnej jako tematu andragogicznego w perspektywie przemian cywilizacyjno-kulturowych.

Następnie odbył się pierwszy panel ekspercki, moderowany przez dr Joannę Golonkę-Legut, dotyczący współczesnych badań nad edukacją dorosłych. Eksperci 
biorący udział w panelu: dr hab. Zofia Szarota, prof. WSB, dr hab. Artur Fabiś, prof. UP, dr hab. Martyna Pryszmont, dr hab. Arkadiusz Wąsiński, podjęli refleksję nad specyfiką realizacji badań andragogicznych i nad edukacją dorosłych. Zwrócili też uwagę na kwestię rozumienia tożsamości i roli zarówno współczesnego badacza - andragoga, jak i recenzenta prac, raportów z badań. Jednocześnie poszukiwali odpowiedzi na pytania dotyczące takich zagadnień, jak: podmiotowość badacza, zaufanie badaczowi, wierność metodzie badawczej.

Po panelu nastąpiły obrady w trzech sekcjach tematycznych dotyczących następujących zagadnień: narracji, biografii i biegu życia w edukacji dorostych (1); zmian mediów i zdalnego nauczania w edukacji dorostych (2) oraz zdrowia, wsparcia i inkluzji społecznej w edukacji dorostych (3). W obradach udział wzięli: dr hab. prof. UWr, Edyta Zierkiewicz, dr hab. Krystyna Dziubacka, dr hab. Piotr Kwiatkowski, dr Emilia Mazurek, dr Justyna Sztobryn-Bochomulska, dr Karolina Kuryś-Szyncel, dr Anna Kowal-Orczykowska, dr Luba Ślósarz, dr Iwona Mazur, dr Anna Kławsiuć-Zduńczyk, dr Małgorzata Buchla, dr Marcin Muszyński, dr Magdalena Barańska, dr Monika Christoph, dr Sonia Wawrzyniak, dr Ewa Jurczyk-Romanowska, dr Ewa Dębska, dr Katarzyna Pardej, mgr Klaudia Izabela Majewska, mgr Beata Działa i mgr Tomasz Kwoka.

Drugi dzień konferencji rozpoczął się sesją plenarną, która została zatytułowana: Perspektywy andragogiki - między presja rynku a tradycja akademii. Obrady rozpoczął prof. dr hab. Józef Kargul, wygłaszając referat o znaczeniu i roli andragoga w procesie edukacji dorosłych. Następnie głos zabrali kolejno: dr hab. Hanna Solarczyk-Szwec, prof. UMK, odnosząca się do polityki uczenia się przez całe życie w Polsce z perspektywy pedagogiki oraz dr hab. Agnieszka Stopińska-Pająk, prof. AWSB, rozważająca przyszłość andragogiki w odniesieniu do wymagań rynku i tradycji akademii.

Po sesji plenarnej rozpoczęły się obrady w dwóch sekcjach tematycznych dotyczących takich zagadnień jak: wiedza, zarzadzanie i tutoring w edukacji dorostych (1) oraz codzienność sztuki i komunikacji w edukacji dorostych (2). W ramach obrad swoje wystąpienia zaprezentowali: prof. dr hab. Mirosława Nowak-Dziemianowicz, dr hab., prof. ASP, Anna Perkowska-Klejman, dr Krzysztof Pierścieniak, dr Marek Podgórny, dr Violetta Podgórna, dr Anna Wawrzonek, dr Rozalia Ligus, dr Aleksandra Litawa, dr Danuta Parlak, mgr Hanna Achremowicz oraz mgr Roksana Pilawska-Gronostaj.

Ostatnią częścią konferencji był panel ekspercki: post-prawda, antyintelektualizm i populizm jako edukacyjne wyzwania, który moderowany był przez dra hab. Witolda Jakubowskiego. W panelu głos zabrali: dr hab. Alicja Jurgiel-Aleksander, prof. UG, dr hab. Wojciech Horyń, prof. AWL, dr hab. Rafał Włodarczyk, dr hab. Paweł Rudnicki, prof. DSW. Uczestnicy panelu zwrócili m.in. uwagę, iż spojrzenie na populizm, antyintelektualizm jako wyzwanie edukacyjne wiążę się z koniecznością powrotu do odpowiedzi na pytanie, co to znaczy, że szkoła (edukacja) jest publiczna. Poszukiwali odpowiedzi na pytania dotyczące populizmu w teorii 
i praktyce edukacji oraz podjęli namysł nad post-prawdą jako narzędziem walki politycznej.

Konferencja została oficjalnie zakończona przez Przewodniczącą Komitetu Naukowo-Organizacyjnego dr Joannę Golonkę-Legut, która podsumowała czas obrad oraz podziękowała wszystkim uczestnikom i uczestniczkom za niezwykle wartościowe i motywujące do dalszej pracy naukowej (badawczej) spotkanie. Niewątpliwie był to czas intensywnych poszukiwań intelektualnych, interesujących wystąpień oraz burzliwych dyskusji. Co szczególnie cenne i poznawczo wartościowe, uczestnicy z dużą otwartością i refleksyjnością prezentowali własne myśli, dyskutowali, stawiali nowe pytania (nie reprodukując wiedzy wyłącznie przez odnoszenie się do tradycyjnych, ugruntowanych rozwiązań i praktyk). Jednocześnie ze względu na niezwykły jubileusz, który towarzyszył konferencji, XXXIII Forum Pedagogów nie było ograniczone wyłącznie do sfery intelektualnej, ale stanowiło również okazję do utrwalania relacji w środowisku pedagogicznym. Niewątpliwie wydarzenie stało się okazją do rozmowy o tym, co ważne dla kształtowania nauki i wspólnoty akademickiej. 